

\title{
Catholicity Under Heaven: Reformed Ecclesiology and Chinese Visions of Cosmopolitanism
}

\author{
Henry S. Kuo \\ Visiting Assistant Professor of Theology and Ethics, \\ Department of Religion, Ethics and Philosophy, \\ Greensboro College, Greensboro, North Carolina, USA \\ henry.kuo@greensboro.edu
}

\begin{abstract}
Reformed catholicity suffers from a fragility that causes it to easily fragment over comparatively small differences. This study wagers that an important resource that can be useful for addressing this problem is the Chinese philosophy of tianxia. The article introduces the idea of a 'Reformed catholicity under Heaven' by placing a more liberal interpretation of tianxia in conversation with the problems in Reformed approaches to the church's catholicity. In doing so, the article demonstrates tianxia's ecclesiological usefulness while articulating two dimensions of 'Reformed catholicity under Heaven' that can deepen how Reformed churches inhabit catholicity in ways that promote unity.
\end{abstract}

\section{Keywords}

Reformed theology - ecclesiology - catholicity - tianxia - ecumenical theology Chinese philosophy - cosmopolitanism

\section{话说天下大勢, 分久必合, 合久必分。}

'It is said, for great Empires under heaven, division, in time, must lead to unity; and unity, in time, must lead to division.' mine. 